\title{
Verbal Memory Functions in Patients after the Ruptured and Unruptured Cerebral Aneurysm Surgery
}

\author{
Ljiljana Pačić-Turk ${ }^{1}$, Valerija Hauptfeld ${ }^{2}$ Lana Maljković², \\ Ivo Somek ${ }^{2}$ Larissa Kalaus ${ }^{1}$ \\ ${ }^{1}$ Catholic University of Croatia, Department of Psychology, Zagreb, Croatia, ${ }^{2}$ Department \\ of Neurosurgery, Medical School, University of Zagreb, Zagreb
}

\begin{abstract}
A cerebral aneurysm is a bulge in the wall of a brain blood vessel with a risk to rupture. It occurs in about $2 \%$ of the population, somewhat more often in women. Most aneurysms are located in the anterior circulation area. Aneurysm rupture is relatively rare and accounts for $5 \%$ of all cerebrovascular brain incidents. Ruptured and asymptomatic/unruptured aneurysms are often treated surgically at the Department of Neurosurgery, Medical School University of Zagreb. The study included 134 patients after cerebral aneurysm surgery during the last 10 years, and neuropsychological testing was performed on average 77 days after surgery. The average age was 52 years and they completed an average of 12 years of education. In the group of patients included in this study, $40.3 \%$ of them were operated after ruptured, and $59.7 \%$ for unruptured cerebral aneurysm. Most aneurysms were located in the middle cerebral and anterior communicating arteries. With regard to lateralization, there was an equal number of aneurysms located in the right and left hemisphere and bilaterally (on the anterior communicating artery). As part of regular neuropsychological assessment, tests of verbal learning and memory (numerical, logical and mechanical memory) were applied. The aims of the study were to find out whether patients operated for ruptured cerebral aneurysms show greater verbal memory impairments than patients operated for unruptured cerebral aneurysms and whether there was the significant effect of lateralization of aneurysm (to check the interaction effect of both rupture and lateralization on those functions). The results obtained show that, even though there are no statistically significant differences between groups of patients that underwent surgery for ruptured and unruptured brain aneurysm, patients show a trend of somewhat better results on most of the verbal memory functions after surgery for unruptured brain aneurysm. The results show statistically significant difference between groups of patients that underwent surgery for ACoA aneurysm and those with right lateralized cerebral aneurysms on most of the trails on AVLT test. Also, patients with operated ACoA aneurysm have significantly worse scores in learning process (AVLT 3 and AVLT 4) and especially on short-term and long-term verbal memory than the patients who were operated for left or right lateralized aneurysm.
\end{abstract}

Key words: cerebral aneurysm, ruptured cerebral aneurysm, unruptured cerebral aneurysm, verbal memory, lateralisation

Copyright (C) 2021 KBCSM, Zagreb

e-mail: alcoholism.kbcsm@gmail.com•www.http://apr.kbcsm.hr

\section{Correspodence to:}

Ljiljana Pačić-Turk, Catholic University of Croatia,

Department of Psychology, Ilica 242, Zagreb, Croatia

Phone: +385911508958

E-mail: ljpturk@unicath.hr 


\section{Introduction}

Cerebral aneurysm (also intracranial or brain aneurysm) is a bulge in the wall of an artery or blood vessel in the brain with a risk to rupture. There are three types of cerebral aneurysms: the most common type is a saccular (which occurs in 90 percent of cerebral aneurysms) followed by two other types, fusiform and dissecting aneurysms. Cerebral aneurysm is relatively common in humans, with incidence ranges from 10 to 16 per 100000 , it occurs more frequently in females and with the highest incidence of rupture between the ages of 40 and 70 [1-3]. It occurs more frequently in arteries located in the front part of the brain. Approximately $85 \%-95 \%$ of all aneurysms develop at the anterior portion of the cerebral arterial supply $[1,4]$. The anterior communicating artery $(\mathrm{ACoA})$ is one of the most common locations of cerebral aneurysm and it is the most frequent location of cerebral rupture and subarachnoid hemorrhage $(\mathrm{SAH})[3]$, which is frequently correlated with cognitive decline. The incidence rate of SAH is 8 of 100000 per year [5]. In patients with SAH the death rate is almost $50 \%$, while approximately $30 \%$ of the survivors suffer from some neurological impairment [6].

However, patients surviving SAH often experience cognitive dysfunction demonstrated on standardised neuropsychological tests despite the absence of neurological deficits [7-20]. The objective of neuropsychological evaluation is to identify cognitive, emotional and behavioural sequels of cerebral dysfunctions according to Halligan and associates [21]. Therefore, neuropsychologist have a multiple role which includes determination of cognitive and conative changes and monitoring the patient's recovery, especially in different stages of neuropsychological re- habilitation [22]. General neuropsychological deficits within SAH and aneurysm treatment include verbal and visual memory impairments as well as visuoperceptive and visuospatial constructive deficits, impairment of psychomotor speed, language disabilities, mental flexibility and personality changes [15,23-25], but the most common cognitive deficits include memory deterioration, executive function impairment, spatial deficits and aphasia as well as personality changes [15,19,26-28].

The nature and severity of the cognitive impairment mainly depends on the location of the aneurysm [18]. The rupture of ACoA often causes persistent memory deficits (with impaired anterograde memory as the most consistent findings) and personality changes, while ruptures of aneurysms of the internal carotid (ACI) or middle cerebral artery (ACM) often results with aphasic, spatial and memory impairments [18]. Fontanella and associates confirmed memory impairment as the most common deficit occurring after ACoA aneurysm surgery [29]. Long-term memory (both verbal and visual) becomes significantly deficient, while short-term memory can remain intact or only mildly damaged. However, as Bellebaum and associates state, most studies comparing the neuropsychological performance of ACoA patients and patients with ruptured aneurysms in other locations did not yield consistent differences between these two groups [24]. Furthermore, tests of executive functions did not differentiate patients with anterior and posterior lesions [24]. Neuropsychological deficits can persist even after a year and more following the insult $[15,24]$. Several studies found that $30 \%$ to $55 \%$ of patients have deficits in one or more cognitive domain 1-7 years after surgical treatment of ruptured aneurysms $[26,30]$. 
Ljunggren and associates found neuropsychological deficits, with memory loss being the most common, in $83 \%$ of patients tested 3 to 5 years after $\mathrm{SAH}$ (significant changes also have been found in intellectual functions, visual and spatial abilities, speed and formation of ideas with following changes in social activities, emotional control and mood) [26]. Meta-analysis from Al-Khindi and associates, in which they analysed the results of 61 studies confirmed severe memory (approximately $60 \%$ ), executive functions (up to $75 \%$ ) and speech (up to $75 \%$ ) deficits due to aneurysmal SAH [31]. However, most studies of cognitive function after SAH have attributed cognitive impairments to the cerebral damage caused by the bleed rather than the effect of the surgery $[15,32,33]$. Hillis and associates found cognitive impairments in patients 3 months after unruptured intracerebral aneurysms (UIA) treatment similar as those seen after $\mathrm{SAH}$ from a ruptured cerebral aneurysm [34]. Also, Ohue and associates suggested that neuropsychological outcomes following surgery of UIA were not satisfactory, particularly in view of significant memory deficits occurring after surgery [35]. On the other hand, Otawara and associates report opposite results; the patients treated with surgery for non-ruptured aneurysms did not develop any cognitive disorders after operative procedure [36].

The aim of our study was to investigate memory deficits in Croatian patients operated for ruptured and unruptured cerebral aneurysms at Department of Neurosurgery, Medical School University of Zagreb.

The objective was to find out whether patients operated for ruptured cerebral aneurysms show greater memory impairment than patient operated for unruptured cerebral aneurysms and to find out if there is sig- nificant effect of lateralization of aneurysm on cognitive impairment (to check the interaction effect of both rupture and lateralization on those functions).

\section{Subjects and Methods}

\section{Subjects}

The study included 134 patients after the brain aneurysm surgery in time period 20102019. There were 34 or $25,4 \%$ male and 100 or $74,6 \%$ female patients, with the mean age of 51,6 (19-69) and with the mean of 12,0 years of education. In the group of patients included in this study, after the ruptured aneurysm surgery there were 54 or 40,3\% (19 male, 35 female) and 80 patients or 59,7\% were operated after unruptured aneurysm surgery (15 male, 65 female).

As regards the localization the most of the aneurysms were on ACM $(76-56,7 \%)$, followed by ACoA $(37-27,6 \%)$, ACI $(9-6,7 \%)$ and ACA $(5-3,7 \%)$ and artery pericalosa $3-2,2 \%)$. There were only one on ACoP, ACP, AB and callousal artery. There were 16 $(11,9 \%)$ patients with multiple aneurysms. As regards lateralization, there were $36,6 \%$ aneurysms in right and $35,1 \%$ in hemisphere and $28,4 \%$ bilateral (ACoA). As regards lateralization, in the group of patients after the ruptured aneurysm surgery there were 15 in left and 15 in right hemisphere and 24 bilaterally sited, while in the group of patients who underwent surgery of asymptomatic/unruputured aneurysm there were 32 in left, 34 in right and 14 bilaterally sited.

\section{Measuring instruments}

The following types of memory were investigated: numerical memory or memory of numbers, working memory or repeating num- 
bers backwards, verbal-mechanical memory or memory of a list of words, verbal-logical memory or memory of stories. These types of memory were assessed by the following tests: Wechsler Memory Scale (WMS) and Auditory-Verbal Learning Test (AVLT).

a) Wechsler Memory Scale (WMS). Numerical memory or memory of numbers was assessed by numerical memory subtest that is part of the WMS, and it consists of numbers that have to be repeated forward (measure of numerical memory) and backwards (measure of working memory) [37]. Maximum possible score in forward memorizing numbers is 9 , and 8 for backward memorizing. Total score equals the sum of forward and backward number memorizing scores. In our study, the numerical and working memory results were presented and analysed separately.

Verbal-logical memory is measured by the WMS subtest of logical recalling. The subtest contains two short stories and a defined number of points (score) is given to each separate unit of the story. A maximum number of points is 20 . In our study, only one story was read and patients were asked to recall the story immediately upon its reading (short-term memory) and at the end of neuropsychological assessment (long-term memory).

b)Verbal-mechanical memory was assessed by the Auditory-Verbal Learning Test (AVLT), meant for evaluation of shortterm memory, learning curve, learning and memorizing strategies, retroactive and proactive interference and long-term memory [38]. The test contains of two lists of 15 words. The study participant is verbally presented list A for five times and after each presentation the participant is asked to repeat all the words he/she can remember. The results obtained after reading the fifth list indicates memory capacity, and the results from 1 to 5 repetitions show the learning curve. The sixth and seventh repetitions are the measure of short-term and long-term memory, respectively. The result for each word reproduction is total number of repeated words in a trial period.

\section{Procedure}

Neuropsychological assessment was conducted in a time period 1-6 month $(M=77$ days) after the operation of cerebral aneurysm at Department of Neurosurgery, Medical School University of Zagreb, during the time period 2010-2019. Neuropsychological assessment was carried out by an experienced psychologist and included clinical interview and neuropsychological tests described above, as a part of large neuropsychological assessment.

Windows package for statistics was used on data analysis; descriptive statistics and multivariate analysis of variance (MANOVA) as main statistical data processing were used.

\section{Results}

Overall number of patients and their number by relevant groups (ruptured and unruptured aneurysms), as well as descriptives for different measures of verbal memory are shown in Table 1. For a clearer overview, the results for AVLT across levels of independent variables have also been shown in Figure 1.

As it can be seen in Table 2, MANOVA showed a statistically significant multivariate main effect of lateralization, with $16.5 \%$ of variance explained. The main multivariate ef- 
Table 1. Descriptive statistics for AVLT, numbers forwards and backwards and verbal-logical memory of groups of patients with differently lateralized ruptured and unruptured cerebral aneurysms

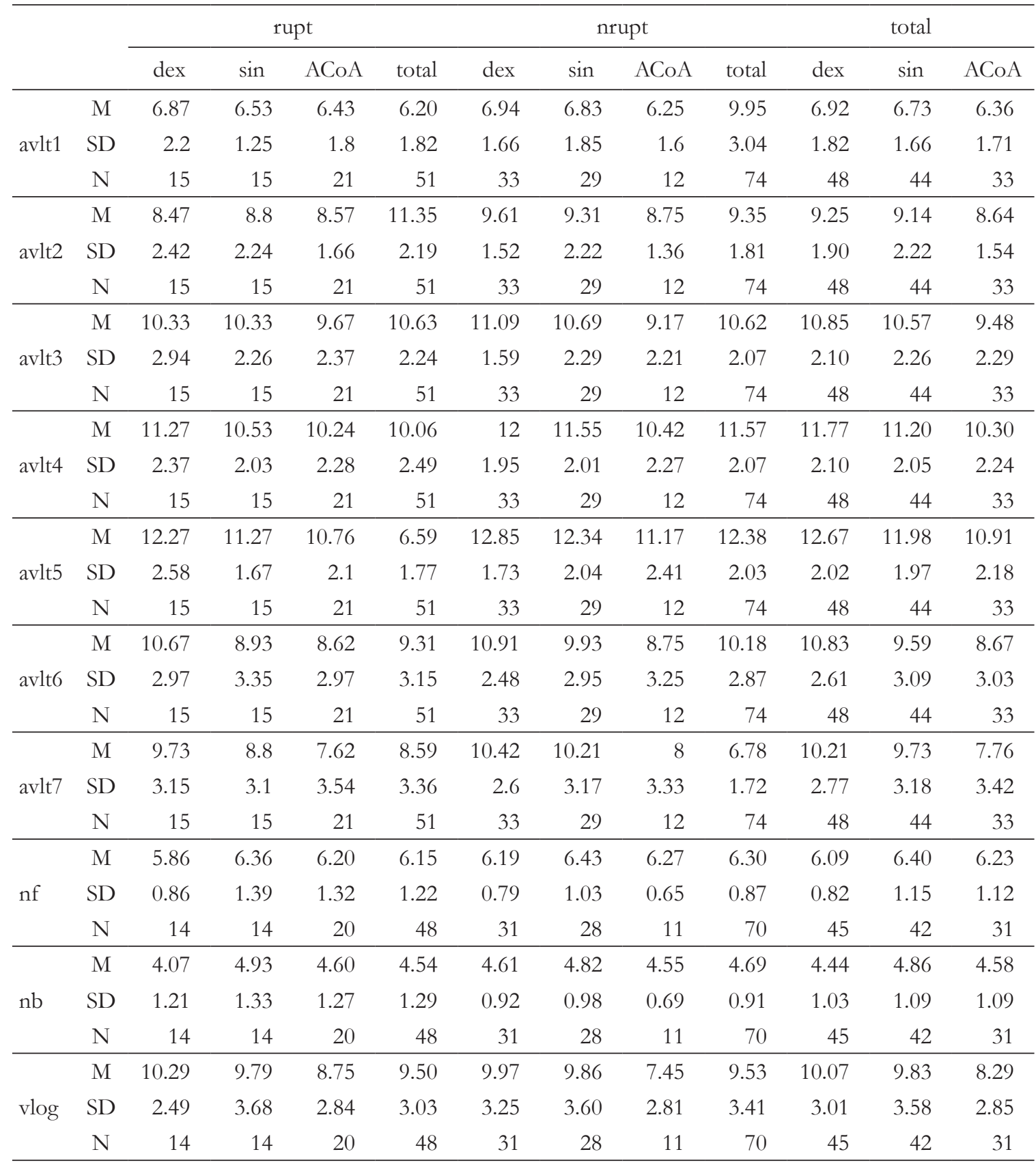

dex - group of patients with right lateralized cerebral aneurysm; sin - group of patients with left lateralized cerebral aneurysm; ACoA - group of patients with anterior communicating artery aneurysm; rup - ruptured aneurysm; nrupt - non ruptured aneurysm; nf - results of WMS subtest Numbers Forward; $\mathrm{nb}$ - results of WMS subtest Numbers Backwards; vlog - verbal-logical memory (stories)

$*_{\mathrm{p}}<0.05 ;{ }^{* *} \mathrm{p}<0.01$ 


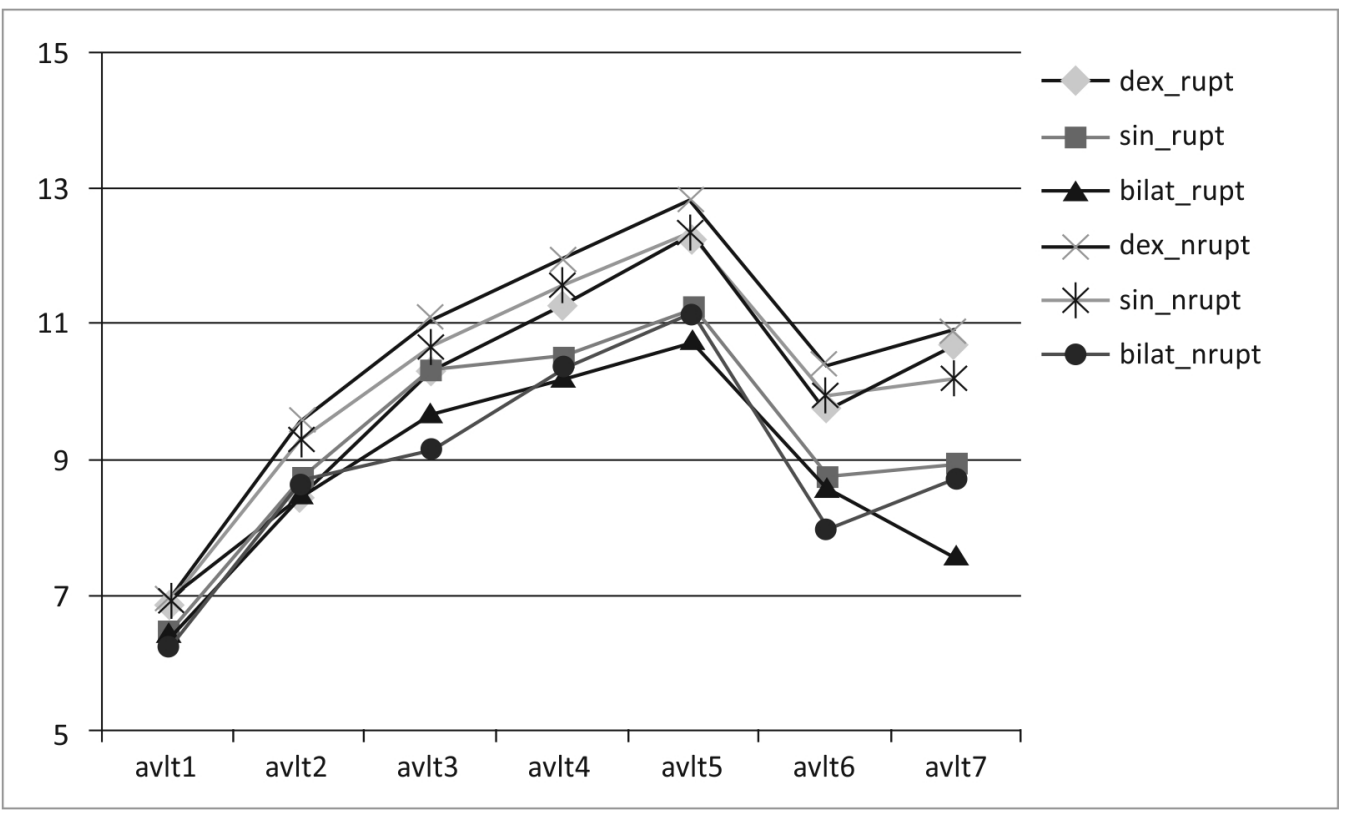

Figure 1. Learning curves (AVLT) for patients with differently lateralized ruptured and unruptured cerebral aneurysms.

fect of rupture, as well as multivariate interaction of rupture and lateralization have failed to reach statistical significance and explain $11.6 \%$ and $4.7 \%$ of total variance, respectively. Even though there are no statistically significant differences between groups of patients that underwent surgery for ruptured $(40.3 \%)$ and unruptured $(59.7 \%)$ brain aneurysm, patients show a trend of somewhat better results on most of the verbal memory functions after surgery for unruptured brain aneurysm.

Table 2. MANOVA results for AVLT and WMS measures for groups of patients with ruptured and unruptured aneurysms with different lateralization

\begin{tabular}{lccccc}
\hline & Wilk's $\lambda$ & $F$ & $d f$ & sig & partial $\eta 2$ \\
\hline Lateralization & 0.698 & 1.828 & 22 & 0.02 & 0.165 \\
Rupture & 0.884 & 1.217 & 11 & 0.285 & 0.116 \\
Lateralization*Rupture & 0.908 & 0.457 & 22 & 0.983 & 0.047 \\
\hline
\end{tabular}

Lateralization - multivariate main effect of lateralization; rupture - multivariate main effect of rupture; lateralization*rupture - multivariate interaction effect of lateralization and rupture, ${ }^{*} \mathrm{p}<0.05 ;{ }^{* *} \mathrm{p}$ $<0.01$ 
Table 3. F-values of univariate effects with corresponding Post-hoc results

\begin{tabular}{lcrcc}
\hline & lateralization & rupture & Lateralization*rupture & Post-hoc \\
\hline AVLT1 & 0.906 & 0.035 & 0.156 & $/$ \\
AVLT2 & 0.445 & 2.750 & 0.590 & $/$ \\
AVLT3 & $3.309^{* *}$ & 0.233 & 0.716 & bilat $<$ dex** \\
AVLT4 & $3.348^{* *}$ & 2.530 & 0.344 & bilat $<$ dex** \\
AVLT5 & $5.360^{*}$ & 3.107 & 0.266 & bilat $<$ dex* $^{*}$ \\
AVLT6 & $4.873^{*}$ & 0.670 & 0.244 & bilat $<$ dex* $^{*}$ \\
AVLT7 & $4.906^{*}$ & 1.944 & 0.260 & bilat $<$ dex* bilat $<$ sin** \\
nf & 1.205 & 0.613 & 0.198 & $/$ \\
nb & 3.601 & 0.356 & 1.040 & $/$ \\
vlog & $2.35^{* *}$ & 0.655 & 0.377 & $/$ \\
\hline
\end{tabular}

Lateralization - univariate main effect of lateralization; rupture - univariate main effect of rupture; lateralization*rupture - univariate interaction effect of lateralization and rupture; ${ }^{*} \mathrm{p}<0.05 ; *_{\mathrm{p}}<0.01$

Further analysis included univariate effects of independent variables in order to determine possible impact of lateralization. In Table 3 obtained F-values and relevant posthoc results showing the direction of those differences are presented. As it can be seen, there is a univariate main effect of lateralization on third (AVLT3), fourth (AVLT4), fifth (AVLT5), sixth (AVLT6) and seventh (AVLT7) trail on AVLT. Other measures do not differ significantly.

Our results show statistically significant difference between groups of patients that underwent surgery for anterior communicating artery aneurysm and those with right lateralized cerebral aneurysms on most of the trails on AVLT. More precisely, group with an anterior communicating artery aneurysm scored on average $1.37(\mathrm{SD}=0.50 ; \mathrm{p}<.05)$, 1.47 (SD=0.49; $\mathrm{p}<.05), 1.76 \quad(\mathrm{SD}=0.46$; $\mathrm{p}<.01), 2.17(\mathrm{SD}=0.66, \mathrm{p}<.01)$ and 2.45 $(\mathrm{SD}=0.70 ; \mathrm{p}<.01)$ points less than the group with right lateralized cerebral aneurysm on AVLT3, AVLT4, AVLT5, AVLT6 and AVLT7, respectively. Also, the group with anterior communicating aneurysm scored 1.97 $(\mathrm{SD}=.71 ; \mathrm{p}<.05)$ points less than the group with left lateralized cerebral aneurysm. In other words, patients with operated bilateral aneurysm (ACoA) had significantly worse scores in learning process (AVLT 3 and AVLT 4) and especially on short-term and long-term verbal memory than the patients who were operated for left or right lateralized aneurysm.

\section{Discussion}

As in studies already mentioned in introduction and according to some other, memory deficits in patients after ruptured brain artery aneurysm and following SAH, as like as in patients with unruptured aneurysms, present the most common deficits [39-41]. Furthermore, Liacona and associates found 
significant memory deficits in patients after surgical treatment of ACoA aneurysm [39]. Such findings were also reported by Stefanova and associates who cited that patients after ACoA aneurysm surgery had deficit of verbal-mechanical short-term and long-term memory following surgical procedures [42].

Even though our study hadn't yield up statistically significant differences in memory deficits between groups of patients with ruptured and unruptured brain aneurysms, we did find that patients show a trend of somewhat better results on most of the verbal memory functions after surgery for unruptured brain aneurysm. Our findings are somewhat in concordance with findings from studies by Otawara and associates, as well as by Hilis and associates, who concluded that, although patients who underwent operation of ruptured aneurysms perform below published norms on many neuropsychological tests, in a minority of patients significant impairments can be seen $[7,34]$.

However, the other finding of this study was the influence of lateralization that is somewhat in concordance with other research in this field that was conducted on the similar group of patients [43]. In our research, patients with operated ACoA (bilateral aneurysm) had significantly worse shortterm and long-term verbal memory than the patients who were operated for either left or right lateralized aneurysm. These results are similar to those reported earlier.

Regarding to the type of treatment, some studies supports evidence to favourable outcome following endovascular coiling treatment rather than surgical clipping $[44,45]$. On the other hand, Bonares and associates in their systematic review cited that although treatment for unruptured intracranial aneurysms allays anxiety, it also results in an ob- servable decline in cognition and daily functioning, and that the decision to treat an unruptured intracranial aneurysm ought to add more weight to the neuropsychological, psychosocial, and functional profiles of these patients [46]. Regarding to that, Bonares and associates did the meta-analysis on the effects of unruptured intracranial aneurysms (UIA) treatment on general cognition with an emphasis on 4 specific cognitive functions: verbal and visual memory, visuospatial functions, and executive functions [47]. The results showed that the treatment of an UIA does not seem to affect long-term cognitive functions. However, these findings should be taken with caution due to paucity of studies addressing this issue.

Due to some methodological issues that weren't included in this study, such as general effects of neurosurgical operation, type of treatment/operation and perioperative management, presence and size of $\mathrm{SAH}$, time span from surgery to neuropsychological testing, compliance with physician's instructions, family support, etc., further studies need to be carried. When interpreting the results, it is important to take into account that this is a relatively small sample, which is also the main limitation of this research. In addition, the number of participants in individual subgroups (e.g., ruptured and non-ruptured aneurysms located in the left or right cerebral hemisphere or bilaterally) is unequal and insufficient. This prevents strong conclusions about possible intergroup differences.

\section{Conclusion}

Even though there are no statistically significant differences between groups of patients that underwent surgery for ruptured and unruptured brain aneurysm, patients 
show a trend of somewhat better results on most of the verbal memory functions after surgery for unruptured brain aneurysm.

The results show statistically significant difference between groups of patients that underwent surgery for anterior communicating cerebral aneurysm and those with right lateralized cerebral aneurysms on most of the trails on Auditory-Verbal Learning Test. Also, the group with anterior communicating aneurysm scored few points less than the group with left lateralized cerebral aneurysm. In other words, patients with op-

\section{References}

1. Phillips LH, Whisnant JP, O'Fallon WM, Sun$\mathrm{dt}$, TM Jr. The unchanging pattern of subarachnoid hemorrhage in a community. Neurology. 1980;30:1034-40.

2. Adams HP, Biller J. Hemorrhagic intracranial vascular disease. In: Baker AB, Joynt RJ, eds. Clinical neurology. Philadelphia, US: Harper \& Row; 1992. p 1-64.

3. McCormick WF. Pathology and pathogenesis of intracranial saccular aneurysms. Seminars in Neurology. 1984;4:291-303.

4. Adams RD, Victor M. Principles of neurology, $11^{\text {th }}$ edition. New York, US: McGraw Hill; 1989.

5. Bederson JB, Connolly ES Jr, Batjer HH, Dacey RG, Dion JE, Diringer MN, et al. Guidelines for the management of aneurysmal subarachnoid hemorrhage: a statement for healthcare professionals from a special writing group of the Stroke Council, American Heart Association. Stroke. 2009;40:994-1025.

6. Suarez JI, Tarr RW, Selman WR. Aneurysmal Subarachnoid Hemorrhage. N Engl J Med. 2006;354:387-96.

7. Otawara Y, Ogasawara K, Kubo Y, Kashimura H, Ogawa A, Yamadate K. Comparison of postoperative cognitive function in patients undergoing erated bilateral aneurysm (ACoA) had significantly worse scores in learning process and especially on short-term and long-term verbal memory than the patients who were operated for left or right lateralized aneurysm.

\section{Acknowledgements}

None.

\section{Conflict of Interest}

The authors report no conflict of interest. surgery for ruptured and unruptured intracranial aneurysm. Surg Neurol. 2009;72:592-5.

8. Gade A. Amnesia after operations on aneurysms of the anterior communicating artery. Surg Neurol. 1982;18:46-9.

9. Haug T, Sorteberg A, Sorteberg W, Lindegaard KF, Lundar T, Finset A. Cognitive outcome after aneurysmal subarachnoid hemorrhage: time course of recovery and relationship to clinical, radiological, and management parameters. Neursurgery. 2007;60:649-57.

10. Hütter BO, Gilsbach JM. Which neuropsychological deficits are hidden behind a good outcome $($ Glasgow $=$ I) after aneurysmal subarachnoid hemorrhage? Neurosurgery. 1993;33:999-1006.

11. Hütter, BO, Kreitschmann-Andermahr I, Gislbach JM. Cognitive deficits in the acute stage after subarachnoid hemorrhage. Neurosurgery. 1998;43:1054-65.

12. Hütter, BO, Kreitschmann-Andermahr, I, Mayfrank L, Rohde V, Spetzger, U, Gilsbach JM. Functional outcome after aneurysmal subarachnoid hemorrhage. Acta Neurochir Suppl. 1999;72:15774.

13. Hütter BO, Kreitschmann-Andermahr I, Gilsbach JM. Health-related quality of life after aneurysmal subarachnoid hemorrhage: impacts of bleeding severity, computerized tomography findings, surgery, 
vasospasm, and neurological grade. J Neurosurg. 2001;94:241-51.

14. Kreiter KT, Copeland D, Bernardin, GL, Bates JE, Peery S, Claassen, et al. Predictors of cognitive dysfunction after subarachnoid hemorrhage. Stroke. 2002;33:200-9.

15. Ogden, J, Mee EW, Henning M. A prospective study of impairment of cognition and memory and recovery after subarachnoid hemorrhage. Neurosurgery. 1993;33:572-87.

16. Powell, J, Kitchen N, Heslin J, Greenwood R. Psychosocial outcomes at three and nine months after good neurological recovery from aneurysmal subarachnoid haemorrhage: predictors and prognosis. J Neurol Neurosurg Psychiatry. 2002;72:772-81.

17. Richardson JT. Cognitive performance following rupture and repair of intracranial aneurysm. Acta Neurol Scand. 1991;83:110-22.

18. Stenhouse LM, Knight RG, Longmor BE, Bishara SN. Long-term cognitive deficits in patients after surgery on aneurysms of the anterior communicating artery. J Neurol Neurosurg Psychiatry. 1991;54:909-14.

19. Vilkki, J, Holst P, Ohman J, Servo A, Heiskanen O. Cognitive deficits related to computed tomographic findings after surgery for a ruptured intracranial aneurysm. Neurosurgery. 1989;25:166-72.

20. Volpe BT, Hirst W. Amnesia following the rupture and repair of an anterior communicating artery aneurysm. J Neurol Neurosurg Psychiatry. 1983;46:704-9.

21. Halligan PW, Kischka U, Marshall JC. Handbook of Clinical Neuropsychology. New York, US: Oxford University Press; 2003.

22. Pačić-Turk, Lj, Kostović-Srzentić M. Klinička neuropsihologija. Zagreb, HR: Zdravstveno veleučilište; 2011.

23. Berry E, Jones R, West CG, Broen JD. Outcome of subarachnoid haemorrhage. An analysis of surgical variables, cognitive and emotional sequelae related to SPECT scanning. Br J Neurosurg. 1997;11:378-87.

24. Bellebaum C, Schäfers L, Schoch B, Wanke I, Stolke D, Forsting, et al. Clipping versus coiling: neuropsychological follow-up after aneurysmal subarachnoid haemorrhage (SAH). J Clin Exp Neuropsychol. 2004;26:1081-92.
25. Anderson SW, Todd MM, Bradley J, Hindman MD, Clarke W, Torner J, et al. Effects of intraoperative hypothermia on neuropsychological outcomes after intracranial aneurysm surgery. Ann Neurol. 2006;60:518-527.

26. Ljunggren B, Sonesson B, Säveland H, Brandt L. Cognitive impairment and adjustment in patients without neurological deficits after aneurysma lsubarachnoid hemorrhage and early operation. J Neurosurg. 1985;62:673-9.

27. Bornstein, RA, Weir BK, Petruk KC, Disney LB. Neuropsychological function in patients after subarachnoid hemorrhage. Neurosurgery. 1987;21:651-4.

28. Ogden JA, Levin PL, Mee EW. Long-term neuropsychological effects of subarachnoid hemorrhage. Neuropsychiatry Neuropsychol Behav Neurol. 1990;3:260-74.

29. Fontanella M, Perozzo P, Ursone R, Garbossa D, Bergui M. Neuropsychological assessment after microsurgical clipping or endovascular treatment for anterior communicating artery aneurysm. Acta Neurochir. 2003;145:867-72.

30. Ogden, JA, Utley T, Mee EW. Neurological and psychological outcome 4 to 7 years after subarachnoid hemorrhage. Neurosurgery. 1997;41:25-34.

31. Al-Khindi T, MacDonald, RL, Schweizer TA. Cognitive and functional outcome after aneurysmal subarachnoid hemorrhage. Stroke. 2010;41:51936.

32. Hütter, BO, Kreitschmann-Andermahr I, Mayfrank L, Rohde V, Spetzger U, Gilsbach JM. Functional outcome after subarachnoid hemorrhage. Acta Neurochir Suppl. 1999;72:157-74.

33. Tidswell P, Dias PS, Sagar HJ, Mayes A, Battersby RD. Cognitive outcome after aneurysm rupture: Relationship to aneurysm site and preoperative complications. Neurology. 1995;45:875-82.

34. Hillis A, Anderson N, Sampath P, Rigamonti D. Cognitive impairments after surgical repair of ruptured and unruptured aneurysms. J Neurol Neurosurg Psychiatry. 2000;69:608-15.

35. Ohue S, Oka Y, Kumon Y, Ohta, S, Sakaki S, Hatakeyama, et al. Importance of neuropsychological evaluation after surgery in patients with unruptured cerebral aneurysms. Surg Neurol. 2203;59:269-76. 
36. Otawara Y, Ogasawara K, Ogawa A, Yamadate $K$. Cognitive function before and after surgery in patients with unruptured intracranial aneurysm. Stroke. 2005;36:142-3.

37. Šali B, Bele-Potočnik Ž, Onič H. Skale pamćenja WB, oblik I I II, priručnik. Ljubljana, SLO: Zavod SR Slovenije za produktivnost dela; 1987.

38. Lezak MD, Howieson DB, Bigler ED, Tranel D. Neuropsychological Assessment. New York, US: Oxford University Press; 2012.

39. Laiacona M, De Santis A, Barabarotto R, Basso A, Spagnoli D, Capitani E. Neuropsychological followup of patients operated for aneurysms of anterior communicating artery. Cortex. 1989;25;267-73.

40. Bendel P, Koivisto T, Niskanen E, Könönen M, Aikiä M, Hänninen T, et al. Brain atrophy and neuropsychological outcome after treatment of ruptured anterior cerebral artery aneurysms: a voxet-based morphometric study. Neuroradiology. 2009;51:711-22.

41. Pačić-Turk Lj, Jandrijević P, Havelka-Meštrović A. Oporavak pamćenja nakon operacije aneurizme moždanih arterija. Acta Clin Croat. 2019;58:229-39.

42. Stefanova ED, Kostić VS, Ziropadja Lj, Marković M, Očić G. Serial position learning effects in pa- tients with aneurysms of anterior communicating artery. J Clin Exp Neuropsychol. 2002;24:687-94.

43. Pačić-Turk Lj. Čimbenici promjena psihičkih funkcija nakon operacije aneurizme mozgovnih arterija [dissertation]. Zagreb, HR: Medicinski fakultet Sveučilišta u Zagrebu; 2003.

44. Kubo Y, Ogasawara K, Kashimura H, Otawara Y,

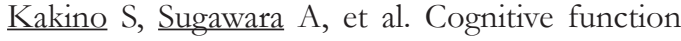
and anxiety before and after surgery for asymptomatic unruptured intracranial aneurysms in elderly patients. World Neurosurg. 2010;73:350-3.

45. Buijs JE, Greebe P, Rinkel GJE. Quality of life, anxiety, and depression in patients with an unruptured intracranial aneurysm with or without aneurysm occlusion. Neurosurgery. 2012;70:868-72.

46. Bonares JM, Leonardo de Oliveira MA, Macdonald RL, Schweizer TA. Behavioral profile of unruptured intracranial aneurysms: a systematic review. Ann Clins Trans Neurol. 2014;1:220-32.

47. Bonares MJ, Egeto P, Leonardo de Oliveira, MA, Vesely KA, Macdonald RL, Schweizer TA. Unruptured intracranial aneurysm treatment effects on cognitive function: a meta-analysis. J Neurosurg. 2016;124:784-90.

\section{Verbalna memorija u bolesnika nakon operacije rupturirane i nerupturirane cerebralne aneurizme}

Sažetak - Cerebralna aneurizma je proširenje cerebralne krvne žile kod kojeg postoji vjerojatnost rupture. Javlja se u oko $2 \%$ populacije, nešto češće kod žena, a većina je smještena je u području prednje cirkulacije. Ruptura aneurizme je relativno rijetka i predstavlja 5\% svih cerebrovaskularnih moždanih incidenata. U Klinici za neurokirurgiju Medicinskog fakulteta Sveučilišta u Zagrebu često se operativno liječe rupturirane, ali i asimptomatske/nerupturirane aneurizme. U ovo istraživanje uključeno je 134 bolesnika operiranih u zadnjih 10 godina, kod kojih je neuropsihologijsko testiranje provedeno u prosjeku 77 dana nakon operacije. Prosječna životna dob ispitanika je bila 52 godine te u prosjeku imaju 12 godina školovanja. U skupini bolesnika uključenih u ovo istraživanje 40.3\% bolesnika operirano je nakon rupture aneurizme, a 59,7\% bolesnika operirano je zbog nerupturirane aneurizme. Najviše je aneurizmi bilo smješteno na srednjoj mozgovnoj i prednjoj komunikantnoj arteriji. S obzirom na lateralizaciju, bio je podjednak broj aneurizmi smještenih u desnoj i lijevoj hemisferi odnosno bilateralno (na prednjoj komunikantnoj arteriji). U okviru redovne neuropsihologijske obrade primijenjeni su testovi verbalnog učenja i pamćenja (numeričko, logičko i mehaničko pamćenje). Cilj istraživanja bio je ustanoviti postoji li razlika u deficitima verbalnog pamćenja u bolesnika nakon operacije rupturiranih i nerupturiranih aneurizmi te postoji li značajan učinak lateralizacije aneurizme (provjeriti interakcijski učinak rupture i lateralizacije na te funkcije). Dobiveni rezultati su pokazali da, iako 
nisu utvrđene statistički značajne razlike između skupine bolesnika operiranih nakon rupturirane aneurizme i nerupturirane aneurizme, $u$ većini ispitivanih funkcija bolesnici nakon operacije rupturirane aneurizme postižu nešto niže rezultate. Rezultati pokazuju statistički značajnu razliku između skupina pacijenata koji su operirani zbog ACoA aneurizme i onih s desnim lateralnim cerebralnim aneurizmama na većini ponavljanja na AVLT testu. Također, pacijenti s operiranom ACoA aneurizmom imaju značajno lošije rezultate u procesu učenja (AVLT3 i AVLT4), a posebno na kratkotročnom i dugoročnom verbalnom pamćenju od pacijenata koji su operirani zbog aneurizme smještene u lijevoj ili desnoj mozgovnoj hemisferi.

Ključne riječi: cerebralna aneurizma, rupturirana cerebralna aneurizma, nerupturirana cerebralna aneurizma, verbalno pamćenje, lateralizacija 